\title{
Rural Capitalisum in Special Economic Region of Tanjung Lesung
}

\author{
Dede Sri Kartini \\ Department of Government \\ Universitas Padjadjaran \\ Bandung, Indonesia \\ dedekartini@yahoo.com
}

\author{
Neneng Yani Yuningsih \\ Department of Government \\ Universitas Padjadjaran \\ Bandung, Indonesia \\ nenengyany@yahoo.co.id
}

\author{
Rahman Mulyawan \\ Department of Government \\ Universitas Padjadjaran \\ Bandung, Indonesia \\ rahmanmulyawan@yahoo.com
}

\begin{abstract}
Capital owner play the role as controller for regional development. This is the center of capitalism, while governments only formulate regulations without monitoring how a rural area should be developed. Ironically, capitalism is supported by public policy. Tanjung Jaya Village once a rural area, now transformed into exclusive place with villa, resort, and beach tourism. This transformation has happened since this village became the first Indonesia Special Economic Region in tourism sector. The aim of this research is describe the management of capitalism from government, both central and local government i.e. Pandeglang Regency.
\end{abstract}

Keywords-Local Government, Policy, Rural Capitalism Keywords-component; formatting; style; styling; insert (key words)

\section{INTRODUCTION}

The functions of government in general are including regulatory, development and service. In carrying out the functions of development, governments in developing countries often trapped in physical development. Economic growth through of foreign capital investment is highly believed to reduce poverty rate. Various regulations are made to facilitate domestic and foreign investment. the construction of luxury hotels and modern recreational facilities are built in the middle of the rural communities which are still unfamiliar with capitalism.

Under similar circumstances, Indonesian government issued policy concerning Special Economic Region (Kawasan Ekonomi Khusus/KEK) which was covered eight regions, i.e. Tanjung Lesung (Banten), Sei Mangkei (North Sumatra), Palu (Central Sulawesi), Bitung (North Sulawesi), Mandalika (NTB), Morotai (Maluku Utara), Tanjung Api-Api (South Sumatra) and Maloi Batuta Trans Kalimantan / MBTK (East Kalimantan).

As one of consideration is KEK Tanjung Lesung is located in Banten. It is a coastal region located in the village Tanjungjaya Panimbang District of Pandeglang and has been known as a tourist destination since it has white sand and a stunning panorama, both on land and underwater. It can be seen from the distribution of coral reefs in this region are known to have an area of about 85 hectares. Beginning with Act No. 39 of 2009 on KEK, then responded with Government Regulation (PP) No. 26 of 2012 concerning on Special Economic Region Tanjung Lesung, reinforce the role of this region as a tourist destination. Product of these policies according to the researchers, have led capitalism in the village of Tanjung Jaya. This government regulation is then responded by Bapedda Pandeglang with Institutional Action Plan, which are consist of : set up Board of KEK, the KEK Board Secretariat, the Administrator of KEK. Action Plan for Delegation of Authority and Establishment of KEK Tanjung Lesung Development Enterprises In addition, the Administrator of KEK is also formed by the Regional Regulation No. 2 of 2014 which facilitate One Stop Integrated Service (Pelayanan Satu Pintu).

Therefore, the central and regional governments had responded on welfare improvement by using modernization concept from historical perspective. This perspective suggests that, from a world historical perspective, modernity is associated with the advantages of a breakthrough innovation or consciousness, moral, ethical, technological, and social order that is useful for the improvement of human welfare [1]. Similar views were expressed by Chodak, modernization is a special and important example of community improvement, an example of a conscious effort which is made to achieve a higher standard of living. Writers formed this arguments, because of development in KEK Tanjung Lesung until now has not been created welfare society. In the contrary the policy has created a dichotomy both geographically, economically and culturally.

Geographic dichotomy can be seen from the condition of villagers' settlements with their simple farming and fishing livelihoods; on the contrary it stands side by side 
with majestic tourist destination and highly secured entrance access. The dichotomy in the economy is more visible, when the residents mostly occupied limited production resources, with private actors dominated the economy in the region -it was exactly what capitalism in countryside is. Culturally, the villagers' who dwells of Tanjung Jaya is still traditional and homogeneous, compared to people who came to KEK Tanjung Lesung which is modern and heterogeneous.

\section{SCOPE OF QUESTIONS}

Globalism and capitalism are two concepts that can not be separated, although this concep is linked in everyday life and often redeemed and shared the same meaning. Globalization has a broader meaning, be it social, political and economic, while capitalism leads to the opening of regulation to increase free and large capital inflows, both regionally and domestically. In this paper will only on "How rural capitalism is regulated?"

\section{DISCUSSION}

Historically, capitalism is inseparable from the role of Weber [2]. Both of these names will be quoted when we look at the history of capitalism. According to Huntington, "there is Weber thesis stating that Protestantism encourage economic enterprises, the bourgeoisie development, capitalism, and economic prosperity, thus facilitate the emergence of democratic institutions". While Fakih said Adam Smith was the first thinker who developed the importance of 'accumulation of capital' in economic development. Adam Smith's theory of the "labor theory of value" later became the basis of capitalism.

Eko [3] create a relation mapping between the state, capital and citizens. In one of his explanations if the change / transformation office are capital owners, then the state usually sells regulation and license as well as protects them. By this way, capital owners gain very large economic and political advantages, while the villagers only received trickle down effect of capitalization, but marginalized and imbalances occurs. As well as stated by Saksono (2015), if the capital owners undertake their economic activities and capital investments are regulated, then there is what we called capitalism.

Development is a determinant aspects that could affect and are affected by the policies made by government. It is positioned as focus of this research, where the government's policy on Special Economic Region (KEK) are in fact government policy which faces of social change in the world that upholds capitalist economic system and consider it as most appropriate system to bring welfare to society. On the other side, this kind of policy also brings social change in traditional societies on the targeted area. Since modernization which also brings development conception, it clearly has certain effects on human personality. The impact of modernity on people reflected urbanism, industrialism, mobility, and communication time.

Economic development which emphasizes on capitalist economic system is something that can not be denied. Theories and concepts into a critic towards this phenomenon often mentioned by social scientists, primarily related to the inability of the capitalist system to provide room to form more equitable prosperity. In fact, this economic system is only able to give an opportunity to the owners of capital to increase the coffers of wealth. As for the wider community, especially people who still believe in traditional values and systems, this kind of economic systems can only worsen their economic situation. Moreover, this community does not posses the ability to compete fairly in free market created by the capitalist economic system. The more aggravated situation is, the policies are made by the government, based on the circumstances in which they are already believed, by achieving community welfare through economic development which leads to modernization and capitalism. Because of this, government's policy is only focused on protecting the interest of capital's owner. Even tough, what are expected by the government in the presence of capital and investments is their abilities to provide stimulus for economic development and in the surrounding community. The government's fault is the lack of preparation for society to be ready and actively participated on economic development.

The author observe that the government was the initiator (policy makers) and also involved in policy implementation. This is proven by various policies which had been issued. Policies at the national level using the Law No. 39/2009 on KEK. From this Act, appear this Presidential Regulation No. 33 of 2010 on the National Council and the Council of Regions KEK. The institutional structure in the development of the SEZ there are two levels, namely, the Board of National Center and the Council of Regions in every province of the region has KEK. At each KEK formed Administrator. Meanwhile, business activity in the SEZ conducted by business entities. Administaror Pandeglang Regency was formed by the Regional Regulation No. 2 of 2014 which runs the OneStop Integrated Service .

Law No. 39 of 2009 on Special Economic Zones [4] provides indications of capitalism in this regulations. Elements of capitalism has begun on the establishment of Special Economic Region requirements, which is stated that one " location map of the development and the proposed area, should be apart from residential areas". Article 6 paragraph 2 explicitly create a dichotomy between KEK and residents, and bring a various consequences both for KEK and residents of the village of Tanjung Jaya where KEK is located. In addition, the product SEZ policy of this Act also shows the arrogance of the central government to the regions. Article 8 stated that the Government may determine an area into KEK without following the requirements accordingly as stipulated in this Law. Regulations which had been ignored by the Government itself are:

a. map of the location of the development and the proposed area separate from the settlements;

b. layout plan of the proposed SEZ equipped with zoning regulations; 
c. plans and financing sources;

d. environmental impact assessment in accordance with the provisions of the legislation;

e. the results of economic and financial feasibility studies; and the duration of an SEZ and strategic plans.

KEK management in Pandeglang given to the Administrator, has given very broad powers to the Regional Technical Institute this. Institutions in this area has tremendous authority, namely:

1) Administrator KEK are in charge of:

a. implement granting business licenses and other permits required for business communities to establish, operate, and develop business in the SEZ;

b. supervising and controlling the operation of the SEZ; and

c. submit reports periodically operationalization KEK and incidental to the Zone Council

2) The granting of licenses referred to in paragraph (1) letter a is done through the One Stop Integrated Service. While article 24 states, Administrator KEK are able to :

a. obtain the delegation or the delegation of authority in the field of licensing from government and regional governments; and

b. ask for clarification to business entities and / or business communities in KEK regarding their business activities.

Those two articles provides a very broad authority, from start giving permission either through delegation of authority from the central government and regional governments, to the supervision and operational control KEK through one door service. Such powers do not exist at the Department or sectors in the whole of government in Indonesia, so the position of Administrator of this very exclusive.

The law is in accordance with Local Regulation No. 2 year 2014 which also states, KEK Administrator have assignment as policy formulator and operator with detail as such:

a. Technical policy formulation in accordance with their scope of duty;

b. Governmental activities and public service in acordance with their scope of duty;

c. Assignment development and executionin accordance with their scope of duty;

d. Other assignment performance given by the Regent in accordance with their duty and function.

Based on said regulation, the writer then try to seek for an alternative to be used as catalytic between the three-which are, government, capital owner private, and welfare seeking community. For that objective, from several concepts and theories which critisize this economic development concept that leads to capitalist system, the writer will borrow the conception from Kanishka Jayasuria as analitical tool.

Based on Jayasuria [5], capitalist economic system that highly regards liberalism value, hold one same characteristic with contemporer format, that lay in the way the see a governance orientated in prosperity. Both try to create liberal subjects planted on economy productive field. Furthermore, those two strands of liberalism comprehend property rights as inherent process formed between social and juridical instead of spontanically appear from market power. The underlying comprehension of market has been changed into public property, but in a way that differ from democratic social logic of social constitutionalism.

Jayasuria on Statecraft, welfare, and politics of inclusion argue that capability or ability of a person may become a mediation and reconciliation key between liberal conception about individual autonomy and social comitment for equality. Government ability and capabilityin involving every existing stakeholderbecome the key to draw together capital interest with community prosperity extensively.

The main point is, Kanishka Jayasuria seek to issued "the third way" as alternative thought to harmonize market system (liberalism) with socialism which naturally put forward common welfare. Of course, the writer thought this alternative is implementable if "statecraft" present, that is the statehood ability of the actor that runs the governance, thus it would be possible to implement a market system while holding the principle of achieving community welfare extensively. The duty of these actors that possess "statecraft" is lay in how they process regulation making to create and theoriticaly understanding a social policy oriented in welfare but within the concept of neo-liberalism market. In formal juridical, law about KEK had already put forward common welfare. Although KEK is capital intensive area, there should be alocation for micro, small, and intermediate business as well as cooperativewithin KEK. In reality, within two years of KEK enforcement in Tanjung Jaya village, that function is still non-existence. The role of government limited in regulation field resulting in KEK administrator arranging price mechanism in the region. This is similar with what initiated by Adam Smith, that government intervention is a natural occurence within economic life [6].

The writer agreed with Lowi, cited by Agustino..liberal policies are those in which the government is used extensively to bring about social change, usually in the direction of ensuring greater level of Social equality. It is true that liberal policy brought fundamental change for community, but that change is unevaluated regarding which group is able or unable in following changes. Liberalism and globalization that usually hand to hand with capitalism are unanticipated, hence the change only prospering the capital owner

To actualized the idea stated above, local government should establish policy oriented in people welfare within capitalist environment. To this day, Local Government of Distict Pendeglang is yet to create derivative regulation to actualize it. There is needs for ideal policy, so that traditional community could stand side by side with the group that owns the capital. Government need to oversee the policy. The question is, has the Law No. 39 year 2009 about KEK been ideal? This question wil be answered using theory cited by Nugroho.

Nugroho [6] ideal policy is said as pragmatism within public policy, meaning the policy model which use "costbenefit" of a policy, such as introduced in Cost benefit analysis paradigm stated by Boardman. Every policy should indeed calculating cost and benefit without ignoring ethical element. According to Molan pragmatism is not identical to oportunism. It is also not merely practisism. Pragmatism leads more toward requirement of every idea to refer to the consequence of its implementation. Pragmatism leans more into goal setting theory, in which every action should point into an objective. Pragmatism should characterize as ethical 
and strategic. Being ethical means pragmatic trait is addressed to public interest instead of elite. According to Nugroho, ideal policy possess these traits:

Table 1

Characteristics of Ideal and Deviate policy

\begin{tabular}{|c|c|}
\hline Ideal & Deviate \\
\hline $\begin{array}{l}\text { Guaranting healthy } \\
\text { competition }\end{array}$ & $\begin{array}{ll}\text { Awarding } & \text { protection } \\
\text { and } & \text { monopoly } \\
\text { without clear limit }\end{array}$ \\
\hline Law assurance & Law bias \\
\hline Proportional tax & $\begin{array}{l}\text { Local tax sucking } \\
\text { awal people ability }\end{array}$ \\
\hline $\begin{array}{l}\text { Empowering business } \\
\text { entities }\end{array}$ & $\begin{array}{l}\text { Selling business } \\
\text { entities in closeout }\end{array}$ \\
\hline $\begin{array}{l}\text { Education based on } \\
\text { global challenge }\end{array}$ & Education uniformity \\
\hline $\begin{array}{l}\text { Building democratic } \\
\text { proficiency }\end{array}$ & $\begin{array}{l}\text { Opening } \\
\text { democracy's tap with } \\
\text { no clear bound }\end{array}$ \\
\hline $\begin{array}{l}\text { Privatisation in the } \\
\text { form of BUMN } \\
\text { ownership dispersion } \\
\text { to domestic public } \\
\text { fairly and equally }\end{array}$ & $\begin{array}{l}\text { Privatisation of } \\
\text { BUMN in the form of } \\
\text { monopoly } \\
\text { transferfrom state to } \\
\text { private, or foreign }\end{array}$ \\
\hline $\begin{array}{l}\text { Proportional subsidy/ } \\
\text { compatible with } \\
\text { desired subsidy target }\end{array}$ & $\begin{array}{l}\text { Unlimited subsidy or } \\
\text { total/exreme subsidy } \\
\text { abolition }\end{array}$ \\
\hline $\begin{array}{l}\text { Equal opportunity for } \\
\text { domestic and global } \\
\text { investor to control } \\
\text { national productive } \\
\text { economy asset }\end{array}$ & $\begin{array}{l}\text { Prioritizing global } \\
\text { investor to take } \\
\text { control over national } \\
\text { productive economy } \\
\text { asset }\end{array}$ \\
\hline $\begin{array}{l}\text { Policy which } \\
\text { guarantee the } \\
\text { implementation of } \\
\text { good governance } \\
\text { principle in every } \\
\text { organisation }\end{array}$ & $\begin{array}{l}\text { Policy which give } \\
\text { discretion right to } \\
\text { group } \\
\text { implementing good } \\
\text { governance }\end{array}$ \\
\hline
\end{tabular}

Source :Nugroho, $2004: 274$

Through Law No. 39 year 2009, government grant leeway for investor in KEK under 9 articles. Those articles begin from article 30 to 39 , in which some is already stated above. This leeway is also law bias since there is no following derivative regulation such as leeway within Earth and Building Tax, import goods, and income tax. This law also prioritizing global investor to take control over national productive economy asset such as hotel construction that take over the area where fishermen looking for fish. Using said policy theory, it is visible here that there are policy derivation.

Government usually could not separate itself from globalization where it clings with capitalism, but government could adapt with its various consequences [7] ). The point is to prepare for possible consequences if they want to adapt to capitalism. Similar with Keohane, Meyer whom opinion cited by Riain stated that globalization is actually a process of emerging new problem for state, but also strengthen world culture principles that nation state is main actor burdened to identified and manage those problems for the sake of community.

\section{CONCLUSION}

a. Local capitalism in KEK Tanjung Lesing deregulation through product of policy Law No. 39 year 2009 about KEK. This law give out leeway for capital owner such as relief on Earth and Building tax, income tax, and import goods. In formal juridical, this policy exist like the third way, become mediator for capitalism area but providing community welfare. In reality, only community who owned the capital able to profit from this policy. This policy also "damage" the system order of local government, since Administrator leveled "Satuan Kerja Perangkat Daerah/Local Officer Working Unit" in the District is given broad authority to manage KEK Tanjung Lesung.

b. In local level, this Law then responded with Local Regulation No. 2 District Pandeglang "Pembentukan Organisasi Perangkat Daerah/Establishment of Local Officer Organisation District Pandeglang" . Through this regulation, Administratur is authorized to execute District Council policy, as well as formulating and executing local policy related to KEK in district level.

\section{REFFERENCES}

[1] Sztompka, Piotr. 2011. Sosiologi Perubahan Sosial. (Penerjemah : Alimandan). Prenada Media Group : Jakarta

[2] Fakih, Mansour. 2013. Runtuhnya Teori Pembangunan dan Globlisasi. Pustaka Pelajar : Yogyakarta.

[3] Eko, Sutoro, dkk. 2013. Mutiara Perubahan : Inovasi dan Emansipasi Desa Dari Indonesia Timur. ACCESS Phase II dan IRE : Yogyakarta.

[4] The laws about Special Ekonomic Zones No. 39/2009.

[5] Jayasuriya, Kanishka. 2006. State Craft, Welfare and The Politics of Inclusion. PalgraveMcmillan : New York.

[6] Nayak,Pullin B. 1996. The State and The Market. Economic andPoliticalWeekly, Vol. 31, No. 4 (Jan. 27, 1996), pp. PE18-PE22.

[7] Nugroho D, Riant. 2004. Kebijakan Publik Formulasi, Implementasi dan Evaluasi. PT. Gramedia. Jakarta.

[8] Keohane, Robert O and John D. Donahue. Introduction. in Joseph S. Nyeand John D. Donahue (Eds). 2000. Governance In A Globalizing World. BrookingInstitution Press : Washington. 